\title{
Droplet spectrum at different vapour pressure deficits ${ }^{1}$
}

\author{
Espectro de gotas em diferentes déficits de pressão de saturação de vapor d'água
}

\author{
Christiam Felipe Silva Maciel ${ }^{2}$, Mauri Martins Teixeira ${ }^{3}$, Haroldo Carlos Fernandes ${ }^{3}$, Sérgio Zolnier ${ }^{3}$ e Paulo \\ Roberto Cecon ${ }^{4}$
}

\begin{abstract}
An efficient pesticides spraying depends a lot in psychrometric conditions, mainly if it is using fine droplets, once climatic conditions may cause droplets evaporation and consequent financial loss to the farmer. Thus, the aim of this work was to determine the droplet spectrum depending on the vapour pressure deficits. The work was carried out inside of a climate chamber to obtain the vapour pressure deficits $\left(\mathrm{VPD}_{\text {air }}\right.$ ). The laser particle analyzer, model Spraytech, was used to determine the droplet spectrum, and the experiment was conducted in factorial scheme $5 \mathrm{x} 20$, consisted of five working pressures $(100 ; 200 ; 300 ; 400$ and $500 \mathrm{kPa})$ and twenty $\mathrm{VPD}_{\text {air }}(2.3 ; 3.2 ; 4.2 ; 5.6 ; 7.0 ; 7.4$; $9.5 ; 11.7 ; 12.7 ; 15.8 ; 16.4 ; 16.9 ; 21.2 ; 22.1 ; 22.2 ; 28.1 ; 29.7 ; 36.939 .4$ e $51.6 \mathrm{hPa})$, in completely randomized design with five replications. There is influence of $\mathrm{VPD}_{\text {air }}$ on droplet spectrum behavior. Increasing the $\mathrm{VPD}_{\text {air }}$ reduces the percentage of sprayed volume comprised by droplets with diameter between 100 and $200 \mu \mathrm{m}$, between 200 and $300 \mu \mathrm{m}$, between 300 and $400 \mu \mathrm{m}$, between 400 and $500 \mu \mathrm{m}$ and between 500 and $600 \mu \mathrm{m}$. Increasing $\mathrm{VPD}_{\text {air }}$ increases the VMD, $\mathrm{Dv}_{90}$, SPAN and the percentage of sprayed volume comprised by droplets larger than $600 \mu \mathrm{m}$.
\end{abstract}

Key words: Droplets diameter. Droplets evaporation. Hydraulic spraying. Spraying technology.

RESUMO - Uma pulverização de agrotóxicos eficiente depende muito das condições psicrométricas do ar, principalmente quando se utiliza de gotas finas, uma vez que condições climáticas adversas podem gerar evaporação de gotas e consequente prejuízo ao agricultor. Assim, objetivou-se com este trabalho determinar o espectro de gotas em diferentes déficits de pressão de saturação de vapor d'água no ar. O experimento foi realizado dentro de uma câmara climática para permitir a obtenção dos déficits de pressão de saturação de vapor d'água no ar $\left(\mathrm{DPV}_{\mathrm{ar}}\right)$. Para a determinação do espectro de gotas, empregou-se o analisador de partículas a laser modelo Spraytech, e o ensaio foi conduzido em esquema fatorial de 5 x 20, constituído por cinco pressões de trabalho $(100 ; 200 ; 300 ; 400$ e $500 \mathrm{kPa})$ e vinte $\operatorname{DPV}_{\text {ar }}(2,3 ; 3,2 ; 4,2 ; 5,6 ; 7,0$; $7,4 ; 9,5 ; 11,7 ; 12,7 ; 15,8 ; 16,4 ; 16,9 ; 21,2 ; 22,1 ; 22,2 ; 28,1 ; 29,7 ; 36,939,4$ e $51,6 \mathrm{hPa})$ no delineamento inteiramente casualizado e com cinco repetições. Houve influência do $\mathrm{DPV}_{\mathrm{ar}}$ no comportamento do espectro de gotas. O aumento do $\mathrm{DPV}_{\mathrm{ar}}$ reduziu a porcentagem do volume pulverizado composta por gotas com diâmetro entre 100 e $200 \mu \mathrm{m}$, entre $200 \mathrm{e}$ $300 \mu \mathrm{m}$, entre 300 e $400 \mu \mathrm{m}$, entre 400 e $500 \mu \mathrm{m}$ e entre 500 e $600 \mu \mathrm{m}$. O aumento do DPV ar aumentou o DMV, o Dv ${ }_{90}$, o SPAN e a porcentagem do volume pulverizado composto por gotas maiores que $600 \mu \mathrm{m}$.

Palavras-chave: Diâmetro de gotas. Evaporação de gotas. Pulverização hidráulica. Tecnologia de aplicação.

\footnotetext{
DOI: $10.5935 / 1806-6690.20160005$

* Autor para correspondência

${ }^{1}$ Recebido para publicação em 09/04/2014; aprovado em 24/09/2015

Extraído da Dissertação de Mestrado do primeiro autor e apresentada no Programa de Pós-Graduação em Engenharia Agrícola da Universidade Federal de Viçosa

${ }^{2}$ Departamento de Engenharia Agrícola, Centro de Ciências Agrárias, Universidade Federal de Viçosa. Av. Ph Rolfs, s/n. Centro, Viçosa-MG, Brasil, 36.570-900, christiam.maciel@ufv.br

${ }^{3}$ Departamento de Engenharia Agrícola, Centro de Ciências Agrárias, Universidade Federal de Viçosa, Viçosa-MG, Brasil, mauriufv@gmail.com, haroldoufv@gmail.com, zolnier@ufv.br

${ }^{4}$ Departamento de Estatística, Centro de Ciências Exatas, Universidade Federal de Viçosa, Viçosa-MG, Brasil, cecon@ufv.br
} 


\section{INTRODUCTION}

One of the most important barriers to obtaining quality spraying is evaporation of the droplets before they reach, or even before they are absorbed by the target, whether this be the crop or a weed. This can result in the inefficient or ineffective application of pesticides, leading to losses for the farmer, impacts on the environment and the poisoning of people.

The evaporation of droplets, together with drift, can represent a $45 \%$ loss in the volume being applied (CHAIM et al., 1999), and although droplets can be lost by evaporation under any weather conditions, losses are less at lower temperatures and under conditions of higher relative humidity (COUTINHO; CORDEIRO, 2004).

Nascimento et al. (2012) observed that spraying with fine to medium droplets resulted in significantly lower deposition at times when the temperature is 34.2 ${ }^{\circ} \mathrm{C}$ and the relative humidity is $29 \%$, compared to when the temperature is $18{ }^{\circ} \mathrm{C}$ and the relative humidity is $78 \%$, but saw no significant differences for sprays of large droplets. Balan et al. (2008) and Souza; Castro and Palladini (2007) obtained similar results, noting that when spraying with fine droplets, deposition of the mixture was reduced for an increase in temperature and a decrease in relative humidity.

Such evaporation take place because the conditions of low relative humidity and high air temperature cause the rapid evaporation of droplets, and consequently increase losses due to drift (TOBI et al., 2011). Drift occurs mainly with droplets smaller than $100 \mu \mathrm{m}$, so that these droplets serve as a more efficient indicator of drift than the VMD (ARVIDSSON; BERGSTRÖM; KREUGER, 2011).

Therefore, in order to prevent evaporation, the ideal time for spraying should be when psychrometric conditions show air temperatures of between 15 and $30{ }^{\circ} \mathrm{C}$ and a minimum relative humidity of $60 \%$. The wind speed should also be noted, and should be within the range of 3 to $7 \mathrm{~km} \mathrm{~h}^{-1}$, in order to avoid convective air currents when the speed is low, and drift at higher speeds (RAETANO, 2011).

It is not only the psychrometric conditions of the air and the diameter of the droplets that influence evaporation, but also the surface to be deposited, such as leaves with hydrophobic, hydrophilic, waxy or hairy surfaces, and the droplet composition, with these containing surfactants or drift reducers (GIMENES et al., 2013; XU et al., 2010a; XU et al., 2010b; XU et al., 2011; YU et al., 2009a; YU et al., 2009b).

The vapour pressure deficit in the air $\left(\mathrm{VPD}_{\text {air }}\right)$ is often used in studies related to droplet evaporation to characterise the psychrometric conditions of the air, this being the difference between the pressure of saturated water vapour in the air and the partial pressure of water vapour, which are both directly related to the relative humidity and air temperature (RODRIGUES et al., 2011; VIANELLO; ALVES, 2012). Arvidsson, Bergström and Kreuger (2011) state that the rate at which water droplets evaporate depends almost entirely on the droplet diameter, and on the VPD ${ }_{\text {air }}$ between the droplet surface and the surrounding air.

Due to the great influence of the psychrometric conditions on spraying, the aim of this work was to determine the droplet spectrum as a function of the vapour pressure deficit, in order to guarantee effectiveness and maximise efficiency in the application of pesticides.

\section{MATERIAL AND METHODS}

The experiment was carried out at the Department of Agricultural Engineering on the campus of the Federal University of Viçosa in the state of Minas Gerais, Brazil. The climate in the region, according to the Köppen classification, is type Cwa, i.e. mesothermal (warm temperate), with rainy summers and dry winters, and an average temperature for the warmest month of over $22{ }^{\circ} \mathrm{C}$ (VIANELLO; ALVES, 2012).

The experiments were conducted inside a climate chamber in order to obtain the psychrometric conditions used in the study. The chamber has a volume of $9.7 \mathrm{~m}^{3}$, and can control relative humidity in the range of 30 to $90 \%$, and the air temperature from 0 to $40^{\circ} \mathrm{C}$.

The vapour pressure deficit in the air $\left(\mathrm{VPD}_{\text {air }}\right)$ was calculated with the Tetens equation (RODRIGUES et al., 2011; VIANELLO; ALVES, 2012), and obtained from the difference between the saturation pressure of water vapour in the air $\left(\mathrm{e}_{\mathrm{s}}\right)$ and the partial pressure of water vapour (e). To calculate $e_{\mathrm{s}}$, the value for air temperature was considered, as per Equation 1.

$\mathrm{e}_{\mathrm{s}}=6.1078^{(10) 7.5} \mathrm{t} / 237.3+\mathrm{t}$

where: $\mathrm{e}_{\mathrm{s}}=$ saturation pressure of water vapour in the air $(\mathrm{hPa})$; and $t=$ air temperature $\left({ }^{\circ} \mathrm{C}\right)$.

The value for $e$ was then determined from the relative humidity and the value for $\mathrm{e}_{\mathrm{s}}$.

$e=\frac{R H_{e s}}{100}$

where: $e=$ partial pressure of water vapour in the air $(\mathrm{hPa})$; and $R H=$ relative humidity $(\%)$.

Finally, the VPD ${ }_{\text {air }}$ was obtained as shown below, by the difference between $\mathrm{e}_{\mathrm{s}}$ and $\mathrm{e}$. 
$\mathrm{DPV}_{\text {air }}=\mathrm{e}_{\mathrm{s}}-e$

where: $\mathrm{DPV}_{\text {air }}=$ vapour pressure deficit $(\mathrm{hPa})$.

The conditions of temperature and relative humidity to obtain the $\mathrm{DPV}_{\text {air }}$ were set up intentionally to represent situations both favourable and unfavourable to spraying, in order to evaluate the effect of the temperature and relative humidity on the spray. Temperature values of 20 , $25,30,35$ and $40^{\circ} \mathrm{C}$ were therefore combined with values for relative humidity of 30,50, 70 and $90 \%$, making it possible to evaluate the evaporation of the sprayed liquid under 20 distinct conditions of DPVair (2.3, 3.2, 4.2, 5.6, 7.0, 7.4, 9.5, 11.7, 12.7, 15.8, 16.4, 16.9, 21.2, 22.1, 22.2, 28.1, 29.7, 36.9, 39.4 and $51.6 \mathrm{hPa}$ ).

To measure the psychrometric conditions of the air inside the climate chamber, a humidity and temperature probe was used (model HMP60, Vaisala, Woburn, MA, USA), which has a measuring range of 0 to $100 \%$ and -40 to $+60^{\circ} \mathrm{C}$. The analogue signals of the electrical voltage from the two sensors were converted into digital signals by means of a microcontroller (model ATmega328, Duemilanove, Arduino, Ivrea, Turin, Italy) and then sent to a computer by serial data transmission.

The working pressures used in determining the droplet spectrum were 100, 200, 300, 400 and $500 \mathrm{kPa}$. These results were obtained with a stationary sprayer (model S-12, Yamaho, Diadema, SP, Brazil), having a rotation of $800 \mathrm{rpm}$, nominal flow rate of $12 \mathrm{~L} \mathrm{~min}^{-1}$, power of 0.75 to $1.12 \mathrm{~kW}$, and maximum pressure of $3516 \mathrm{kPa}$. The sprayer was driven by an electric motor (model F56H, Weg, Jaragua do Sul, Santa Catarina, Brazil), with a rotation of $3,570 \mathrm{rpm}$ and power of $1.5 \mathrm{~kW}$. The droplets were analysed by a laser particle analyser (model Spraytech, Malvern Instruments Ltd., Malvern, Worcestershire, UK). This instrument has a focal length of $750 \mathrm{~mm}$, and uses the technique of laser diffraction for measuring the size of the sprayed droplets. This technique measures the intensity of light that is scattered as a laser beam passes through a sprayed jet. The data are then analysed to calculate the size of the droplets that created the scattering profile. The analyser was calibrated to count droplets in the size class of 0.10 to $2,500 \mu \mathrm{m}$.

Study of the droplet spectrum included the following indicators: $\mathrm{VMD}, \mathrm{D}_{\mathrm{v} 10}, \mathrm{Dv}_{90}$, span, and the percentage of spray volume containing droplets smaller than $100 \mu \mathrm{m}$ $(\% \mathrm{~V}<100)$, droplets with a diameter between 100 and $200 \mu \mathrm{m}(100<\% \mathrm{~V}<200)$, a diameter between 200 and $300 \mu \mathrm{m}(200<\% \mathrm{~V}<300)$, a diameter between 300 and $400 \mu \mathrm{m}(300<\% \mathrm{~V}<400)$, a diameter between 400 and $500 \mu \mathrm{m}(400<\% \mathrm{~V}<500)$, a diameter between 500 and $600 \mu \mathrm{m}(500<\mathrm{V} \%<600)$, and finally, droplets greater than $600 \mu \mathrm{m}(\% \mathrm{~V}>600)$.
The liquid was sprayed over the particle analyser in such a way that the entire jet from the nozzle passed transversely across the light beam emitted by the laser. To do this, a spray boom was mounted on the analyser, and an electric motor installed at the end of the boom to allow the boom to revolve, ensuring the complete analysis of the jet from the nozzle. The spray boom consisted of a nozzle and pressure gauge. The electric motor installed at the end of the boom was a type CEP, of $12 \mathrm{~V}$ and $7.5 \mathrm{~A}$, with a torque of 25 to $48 \mathrm{mN}$, and a maximum speed of $10.47 \mathrm{rad} \mathrm{s}^{-1}(100 \mathrm{rpm})$.

For the experiment, five similar hydraulic nozzles were used (model Lurmark LD11002, Hypro EU Ltd, Longstanton, Cambridgeshire, UK), which were chosen at random from a set of 20 nozzles, as per ISO 5682-1 (1996). These nozzles were positioned on the spray boom at a distance of $0.50 \mathrm{~m}$ from the laser beam emitted by the particle analyser, representing the height of the spray boom in relation to the crop. The water used throughout the experiment was obtained directly from a tap, as is recommended by ASAE standard S572.1 (2009).

The experiment was carried out in a $5 \times 20$ factorial scheme, comprising the 5 working pressures and the 20 values for DPVair, in a completely randomised design, with five replications. The data were evaluated using response surface methodology. The models were chosen based on the significance of the regression coefficients by t-test, adopting a significance level of $10 \%$ for the coefficient of determination and for the behaviour of the variance under study.

\section{RESULTS AND DISCUSSION}

The VMD, which is the primary parameter studied in the droplet spectrum, increased with the increase in $\mathrm{VPD}_{\text {air }}$ and reduction in the operating pressure, with the lowest value being $152.77 \mu \mathrm{m}$ at a pressure of $500 \mathrm{kPa}$ and $\mathrm{VPD}_{\text {air }}$ of $2.3 \mathrm{hPa}$, and the highest being $256.92 \mu \mathrm{m}$ at a pressure of $100 \mathrm{kPa}$ and $\mathrm{VPD}_{\text {air }}$ of $51.6 \mathrm{hPa}$ (Figure 1a). In a similar way to the VMD, the $\mathrm{Dv}_{90}$ and the span increased with the increase in $\mathrm{VPD}_{\text {air }}$ and reduction in working pressure (Figures $1 \mathrm{c}$ and $1 \mathrm{~d}$ ). Yet the $\mathrm{Dv}_{10}$ displayed a negative trend with the increase in working pressure and $\mathrm{VPD}_{\text {air }}$. At high pressures however, an increase in VPD generated an increase in $\mathrm{Dv}_{10}$, this increase being produced by the total evaporation of the small droplets (Figure 1b).

With the increase in $\mathrm{VPD}_{\text {air, }}$ a reduction is expected in droplet diameter, since such an increase favours evaporation; but results show that the VMD increased due to a complete evaporation of the very fine droplets. Alvarenga et al. (2013), working at a pressure of $1,055 \mathrm{kPa}$ and with a JA-2 nozzle, reported that the 
Figure 1 - Estimates of the volumetric median diameter, the droplet diameter below which is found $10 \%$ of the total volume of sprayed liquid, the droplet diameter below which is found $90 \%$ of the total volume of sprayed liquid, and the span, with estimates of the percentage of spray volume containing droplets smaller than $100 \mu \mathrm{m}$, droplets with a diameter from 100 to $200 \mu \mathrm{m}$, a diameter from 200 to $300 \mu \mathrm{m}$, a diameter from 300 to $400 \mu \mathrm{m}$, a diameter from 400 to $500 \mu \mathrm{m}$, a diameter from 500 to $600 \mu \mathrm{m}$, and droplets greater than $600 \mu \mathrm{m}$, for the $\mathrm{VPD}_{\text {air }}$ and working pressure. (a) VMD; (b) $\mathrm{Dv}_{10}$; (c) $\mathrm{Dv}_{90}$; (d) span; (e) $\% \mathrm{~V}<100$; (f) $100<\% \mathrm{~V}<200$; (g) $200<\% \mathrm{~V}<300$; (h) $300<\% \mathrm{~V}<400$; (i) $400<\% \mathrm{~V}<500$; (j) $500<\% \mathrm{~V}<600$; (k) $\%>600$

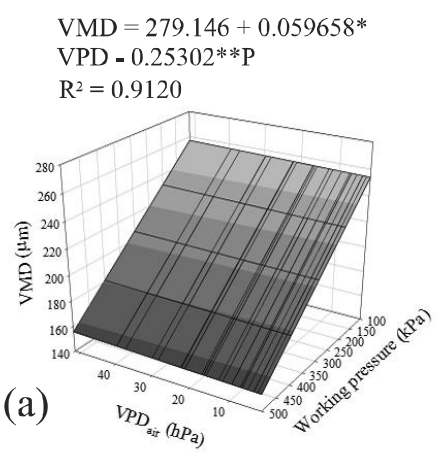

$\mathrm{SPAN}=1.2645+0.00684741^{* *}$ VPD $-0.00005384 \mathrm{P}$

$\mathrm{R}^{2}=0.6016$

(d)

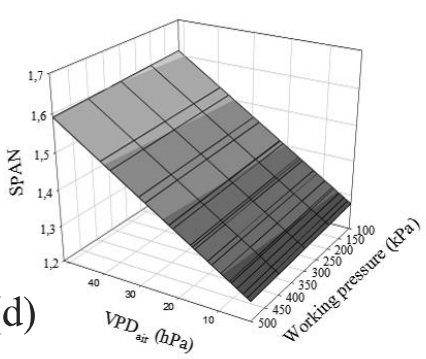

$200<\% \mathrm{~V} 300=33.5975-0.0381865^{* *}$ VPD $-0.0180206 * * \mathrm{P}$

$\mathrm{R}^{2}=0.8603$

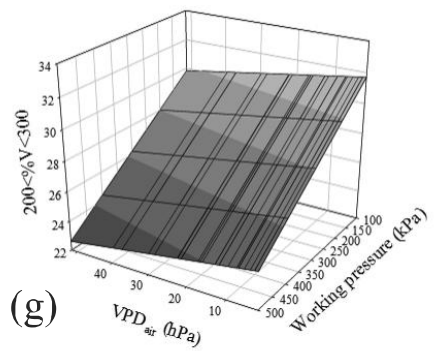

$\mathrm{D}_{\mathrm{v} 10}=149.95-0.122669 * *$

VPD $-0.133629 * * \mathrm{P}+0.00035741 * *\left(\mathrm{VPD}^{*} \mathrm{P}\right)$

$\mathrm{R}^{2}=0.9350$

(b)

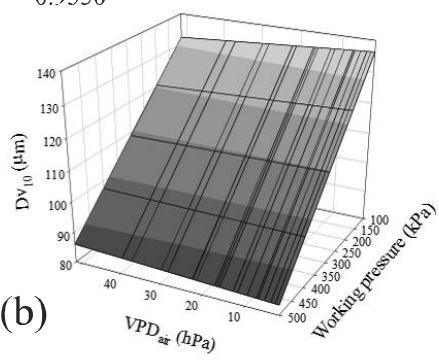

$\% \mathrm{~V}<100=-1.70956+0.0264265 * *$ $\mathrm{VPD}-0.0342073^{* *} \mathrm{P}-0.000097168^{* *}(\mathrm{VPD} * \mathrm{P})$ $\mathrm{R}^{2}=0.9707$

(e)

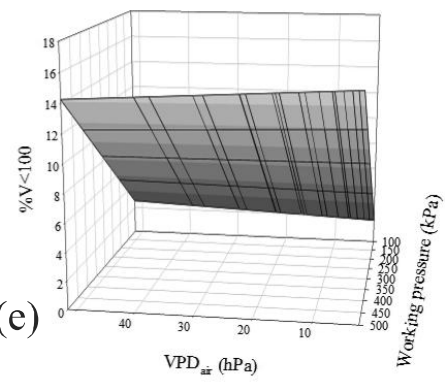

$300<\% \mathrm{~V}<400=22.4144-0.0215974 * *$ VPD $-0.331311 * * P$ $\mathrm{R}^{2}=0.9460$

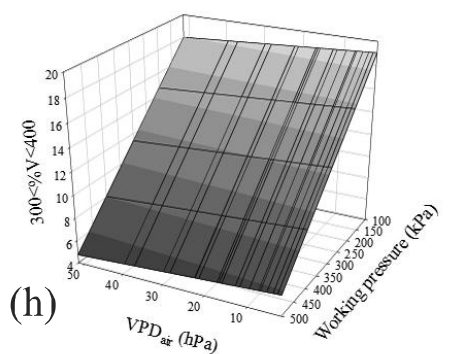

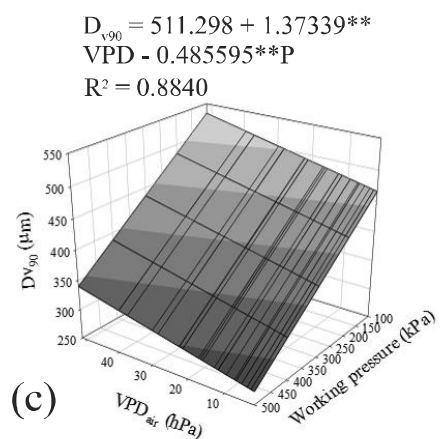

$100<\%$ V200 $=24.1368-0.0350263 * *$ $\mathrm{VPD}+0.0606191^{* *} \mathrm{P}$

$\mathrm{R}^{2}=0.8974$

(f)

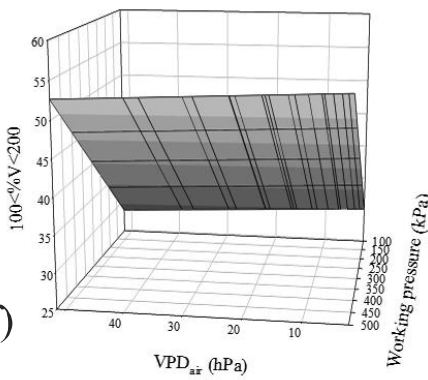

$400<\%$ V $500=12.3465-0.00121412 * *$ VPD - $0.0239046^{* * P}$ $\mathrm{R}^{2}=0.9021$

(i)

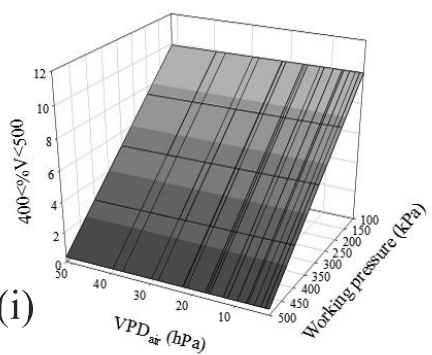

$400<\% \mathrm{~V}<500=12.3465-0.00121412 * *$ VPD $-0.0239046^{* *} \mathrm{P}$ $\mathrm{R}^{2}=0.9021$

(j)

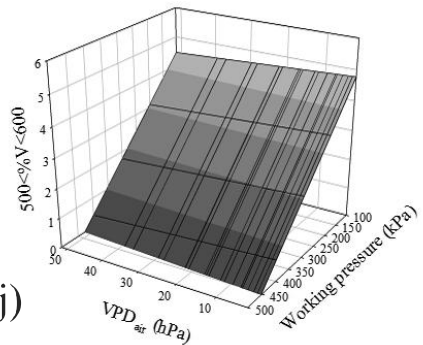

$\% \mathrm{~V}>600=2.55823+0.115523 * *$

VPD $-0.00448536^{* *} \mathrm{P}$

$\mathrm{R}^{2}=0.6124$

(k)

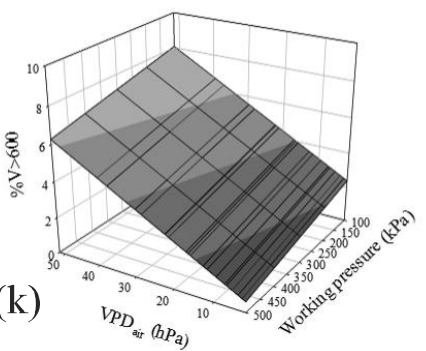

${ }^{* *}$ Significant at $1 \%$ probability by t-test. ${ }^{*}$ Significant at $5 \%$ probability by t-test. ${ }^{\circ}$ Significant at $10 \%$ probability by t-test 
$\mathrm{Dv}_{10}$ and $\mathrm{Dv} \mathrm{v}_{90}$ were reduced with the increase in $\mathrm{VPD}_{\text {air }}$. However, the droplet spectrum was determined using water-sensitive labels, which are not reliable when evaluating a droplet spectrum, since in that situation the droplet diameter is measured from spots that form on the labels, so if two or more droplets should be deposited at the same place, the droplets will coalesce, and the actual diameter will be overestimated.

The span depends on the values of $\mathrm{Dv}_{10}$ and $\mathrm{Dv}_{90}$. When there is a great difference between these values, the span is increased. Alvarenga et al. (2014) however, observed a reduction in the span from the JA-2 nozzle when increasing the VPD air from 7.6 to $26.3 \mathrm{hPa}$; but these authors used water-sensitive labels to evaluate the droplet spectrum. The application of pesticides should be carried out with hydraulic nozzles that have a low span, with a value close to or less than one, since this value ensures that more droplets of a similar diameter are produced.

Keeping the VPD air constant, the percentage of spray volume comprised of droplets smaller than $100 \mu \mathrm{m}$ increases with the increase in working pressure. However, maintaining the pressure constant at low pressures, the increase in VPD $\mathrm{Vir}_{\text {p }}$ produces an increase in the percentage of spray volume composed of droplets smaller than 100 $\mu \mathrm{m}$. At high pressures, the increase in VPD leads to a reduction of this percentage (Figure 1e). This reduction is derived from the complete evaporation of the smaller droplets, and consequently increases the value of $\mathrm{Dv}_{10}$.

The percentage of spray volume composed of droplets with a diameter between 100 and $200 \mu \mathrm{m}$ was reduced with the increase in $\mathrm{VPD}_{\text {air }}$ and reduction of the working pressure (Figure 1f). This shows that nozzles that produce fine droplets actually have poor deposition on the target, as found by Balan et al. (2008), Nascimento et al. (2012) and Souza; Castro and Palladini (2007).

The increase in both VPD air $_{\text {and working }}$ pressure reduced the percentage of spray volume composed of droplets with a diameter between 200 and $300 \mu \mathrm{m}$, between 300 and $400 \mu \mathrm{m}$, between 400 and $500 \mu \mathrm{m}$, and between 500 and $600 \mu \mathrm{m}$ (Figure $1 \mathrm{~g}, 1 \mathrm{~h}, 1 \mathrm{i}$ e $1 \mathrm{j}$ ). Evaporation is helped by raising the $\mathrm{VPD}_{\text {air }}$; therefore, a decrease in the percentage of spray volume composed of droplets of these diameters, for an increase in VPD , means that the sprayed droplets are evaporating. Probably, such evaporation is only not greater because part of the volume lost through the evaporation of droplets in the diameter range of 200 to $300 \mu \mathrm{m}$ is compensated by the evaporation of droplets in the range of 300 to $400 \mu \mathrm{m}$, and so on.

The percentage of spray volume composed of droplets greater than $600 \mu \mathrm{m}$ increased with the increase in $\mathrm{VPD}_{\text {air }}$ and reduction in the working pressure. However, the VPD air had a much greater influence on this variable than did the working pressure (Figure 1k).

An increase in the spray volume comprising droplets greater than $600 \mu \mathrm{m}$ with the increase in VPD occurs due to the high evaporation of smaller droplets. Thus by eliminating the small droplets, there is a reduction in the total spray volume, and consequently, an increase in the percentage of spray volume composed of extremely coarse droplets, since these are less affected by evaporation compared to the finer droplets.

This increase in the percentage of spray volume consisting of droplets larger than $600 \mu \mathrm{m}$ explains the increase seen in the values of $\mathrm{VMD}$ and $\mathrm{Dv}_{90}$ for an increase in $\mathrm{VPD}_{\text {air }}$, these consequently altering the span.

Moreover, the reduction in droplet diameter with an increase in working pressure takes place because as the pressures increases, the amount of liquid that crosses the nozzle orifice is greater, resulting in greater fractionation of the liquid, and the increased production of droplets with reduced diameters.

\section{CONCLUSIONS}

1. The increase in $\mathrm{VPD}_{\text {air }}$ reduces the percentage of spray volume composed of droplets with a diameter from 100 to $200 \mu \mathrm{m}$, from 200 to $300 \mu \mathrm{m}, 300$ to $400 \mu \mathrm{m}, 400$ to $500 \mu \mathrm{m}$, and from 500 to $600 \mu \mathrm{m}$, and increases the $\mathrm{VMD}, \mathrm{Dv}_{90}$, span and percentage of spray volume made up of droplets greater than $600 \mu \mathrm{m}$;

2. Because the droplet spectrum changed with the VPD air, these data show that under critical psychrometric conditions, the climate has a direct influence on the behaviour of the sprayed droplets; before each application of pesticide therefore, it is necessary to be aware of the psychrometric air conditions to ensure that spraying the pesticide is effective and efficient.

\section{REFERENCES}

ALVARENGA, C. B. et al. Déficit de pressão de vapor d'água no ar na distribuição de líquido utilizando um pulverizador hidropneumático. Revista de Ciências Agrárias, v. 56, n. 2, p. 81-87, 2013.

ALVARENGA, C. B. et al. Efeito do déficit de pressão de vapor d'água no ar na pulverização hidropneumática em alvos artificiais. Bioscience Journal, v. 30, n. 1, p. 182-193, 2014.

AMERICAN SOCIETY OF AGRICULTURAL ENGINEERS ASAE. Spray nozzle classification by droplet spectra. ASAE S572.1, St. Joseph, MI, 2009. 4p. 
ARVIDSSON, T.; BERGSTRÖM, L.; KREUGER, J. Spray drift as influenced by meteorological and technical factors. Pest Management Science, v. 67, p. 586-598, 2011.

BALAN, M. G. et al. Deposição da calda pulverizada por três pontas de pulverização sob diferentes condições meteorológicas. Semina: Ciências Agrárias, v. 29, n. 2, p. 293-298, 2008.

CHAIM, A. et al. Método para monitorar perdas na aplicação de agrotóxicos na cultura de tomate. Pesquisa Agropecuária Brasileira, v. 34, n. 5, p. 741-747, 1999.

COUTINHO, P.; CORDEIRO, C. M. A ponta de pulverização - cuidados na escolha. Tecnologia de aplicação de defensivos agrícolas II - Encontro Técnico, 2004, 122 p.

GIMENES, M. J. et al. Dispersion and evaporation of droplets amended with adjuvants on soybeans. Crop Protection, v. 44, p. 84-90, 2013.

INTERNATIONAL ORGANIZATION FOR STANDARDIZATION - ISO. Equipment for crop protection Spraying equipment - Part 1: test methods for sprayer nozzles. ISO 5682-1, Geneva, 1996. 5 p.

NASCIMENTO, A. B. et al. Deposição de glifosato e utilização de adjuvante para diferentes pontas de pulverização e horário de aplicação. Pesquisa Aplicada \& Agrotecnologia, v. 5, n. 2, p. 105-110, 2012.

RAETANO, C. G. Introdução ao estudo da tecnologia de aplicação de produtos fitossanitários. In: ANTUNIASSI, U. R.; BOLLER, W. (Org.). Tecnologia de aplicação para culturas anuais. Passo Fundo: Aldeia Norte; Botucatu: FEPAF, 2011. cap. 1, p. 15-26.

RODRIGUES, H. J. B. et al. Variabilidade sazonal da condutância estomática em um ecossistema de manguezal amazônico e suas relações com variáveis meteorológicas. Revista Brasileira de Meteorologia, v. 26, n. 2, p. 189-196. 2011.

SOUZA, R. T.; CASTRO, R. D.; PALLADINI, L. A. Depósito de pulverização com diferentes padrões de gotas em aplicações na cultura do algodoeiro. Engenharia Agrícola, v. 27, n. especial, p. 75-82, 2007.

VIANELlO, R. L.; ALVES A. R. Meteorologia básica e aplicações. 2. ed. Viçosa: Editora UFV, 2012. 460 p.

TOBI, I. et al. Determination of accuracy level of agricultural spraying application in Sanliurfa/Turkey. African Journal of Agricultural Research, v. 6, n. 28, p. 6064-6072, 2011.

$\mathrm{XU}, \mathrm{L}$. et al. Adjuvant Effects on evaporation time and wetted area of droplets on waxy leaves. Transactions of the ASABE, v. 53, n. 1, p. 13-20, 2010a.

$\mathrm{XU}$, L. et al. Droplet evaporation and spread on waxy and hairy leaves associated with type and concentration of adjuvants. Pest Management Science, v. 67, n. 7, p. 842851, 2011.

XU, L. et al. Evaporation rate and development of wetted area of water droplets with and without surfactants at different locations on waxy leaf surfaces. Biosystems Engineering, v. 106, n. 1, p. 58-67, 2010b.

YU, Y. et al. Evaporation and coverage area of pesticide droplets on hairy and waxy leaves. Biossystems Engineering, v. 104, n. 3, p. 324-334, 2009a.

YU, Y. et al. Evaporation and deposition coverage area of droplets containing insecticides and spray additives on hydrophilic, hydrophobic, and crabapple leaf surfaces. Transactions of the ASABE, v. 52, n. 1, p. 39-49, 2009b. 